\title{
The best late season peaches profile
}

\section{O melhor perfil de pêssego tardio}

\author{
Etiénne Groot ${ }^{1 *}$ (D), Luis Miguel Albisu ${ }^{2}$ \\ 1Universidade Estadual Paulista "Júlio de Mesquita Filho" (Unesp), Faculdade de Ciências Agrárias e Tecnológicas, \\ Dracena/SP - Brasil \\ ${ }^{2}$ Centro de Investigación y Tecnología Agroalimentaria de Aragón (CITA), Unidad de Economía Agroalimentaria y \\ de los Recursos Naturales, Zaragoza - Spain
}

*Corresponding Author: Etiénne Groot, Universidade Estadual Paulista "Júlio de Mesquita Filho" (Unesp), Faculdade de Ciências Agrárias e Tecnológicas, Rod. Cmte João Ribeiro de Barros, km 651, CEP: 17900-000, Dracena/SP - Brasil, e-mail: etienne.groot@unesp.br

Cite as: Groot, E., \& Albisu, L. M. (2020). The best late season peaches profile. Brazilian Journal of Food Technology, 23, e2018330. https://doi.org/10.1590/1981-6723.33018

\begin{abstract}
This work aimed to determine the best late season peaches profile via a Best Worst Discrete Choice Experiment. The survey was performed in the city of Zaragoza - Spain, in October 2008. In total, 316 people stated their preferences towards late season peaches. On average, a peach produced in the Calanda area with Protected Designation of Origin (PDO), weighting around $254 \mathrm{~g}$ and conditioned in normal packaging or in bulk, may be considered the best late season peach. Among different types of analyzed consumers, all preferred peaches with PDO, produced in the Calanda area. Regarding to fruit size, for many types of consumers, the bigger the better. Only for women and consumers over 50 years old, medium size peaches are preferable to the largest ones. In addition to the fruit size, market segmentation should consider the different kinds of packaging.
\end{abstract}

Keywords: Best-worst discrete choice experiment; PDO Calanda peach; Stated preference; Zaragoza; Consumer; Preference.

\section{Resumo}

O objetivo deste trabalho foi determinar o melhor perfil de pêssego tardio. Realizou-se um Experimento de Escolha Discreta do tipo Melhor Pior para cumprir com os objetivos. A pesquisa foi realizada na cidade de Zaragoza Espanha, em outubro de 2008. No total, 316 pessoas declararam suas preferências em relação aos pêssegos tardios. No geral, o melhor pêssego tardio é aquele produzido na região de Calanda, com Denominação de Origem Protegida (DOP), com peso em torno de $254 \mathrm{~g}$ e condicionado em embalagem normal ou a granel. Entre os diferentes tipos de consumidores analisados, todos preferiram pêssegos com DOP, produzidos em Calanda. Quanto ao tamanho da fruta, para vários tipos de consumidores, quanto maior, melhor. Apenas para as mulheres e consumidores com mais de 50 anos de idade, pêssegos de tamanho médio são preferíveis aos de maior tamanho. Além do tamanho, a segmentação de mercado deve considerar os tipos de embalagem.

Palavras-chave: Experimento de escolha discreta-melhor pior; Pêssegos com DOP Calanda; Preferência declarada; Zaragoza; Consumidor; Preferência. 


\section{Introduction}

Since 2008, peach consumption has declined in Spain. Peach consumption was $5.19 \mathrm{~kg}$ per capita and it diminished to $3.73 \mathrm{~kg}$ per capita, in 2015 . This reduction in consumption was partially due to the economic crisis, which Spain has been suffering. Similar trend has been observed in other countries such as Italy, France, Greece and USA. According to Iglesias (2017), the main causes for the decrease of peach consumption is the inconsistent fruit quality (too hard or too soft), lack of taste, the absence of flavor identification related to different varieties (sweet or not), and the absence of brands.

There are initiatives to increase peach production and consumption in Spain. Since 1990 to 2016, twelve breeding programs have mainly focused on producing more adapted cultivars for growing conditions and higher fruit quality (size, color, taste and texture). Four areas of Aragón participated and one of them was focusing on the improvement of peaches produced in the Calanda area (Iglesias, 2017).

In 1999, the Regulatory Council (RC) of peaches with Protected Designation of Origin Calanda (PDO Calanda Peaches) was created with the aim of maintaining the control of peaches produced in the Calanda area, which covers part of Teruel and Zaragoza provinces, in Spain. The peach flesh hardness, at harvest, varies in pressure resistance between 3.5 and $5.0 \mathrm{~kg} / 0.5 \mathrm{~cm}^{2}$ (measured by Magness-Taylor method). The sugar content, which is determined by SSC (Soluble Solid Content), must be at least 12 degrees Brix (Aragón, 2017).

In addition to the fruit characteristics, the high quality of PDO Calanda Peaches is the result of special cultivation techniques, such as fruit manual bagging. The control of the entire production process, from field to consumer, ensures that the peach achieves high quality. Quality differentiation and certification process have an important impact on PDO Calanda Peach cost (Aguaviva, 2015). A premium price in the consumer market is crucial for its economic sustainability.

It is important to know the consumer's behavior in order to guide product quality programs, provide better marketing strategies, and consumer acceptability (Voicu, 2013). There are few studies dealing with consumer preference toward peaches in Spain. This lack of information hampers marketing strategies assessment such as branding, Protected Designation of Origin, fruit size and the use of different packaging in order to boost its production.

The main objective of this research was to study the stated consumers' preferences toward late season peaches through a discrete choice experiment in the city of Zaragoza (Spain) in order to determine the best fruit profile.

This works was structured as follows. The next section explains the employed methodology: Best-Worst Discrete Choice Experiment. The third section presents results, first showing average preferences and then preferences for different consumers' socio-demographics characteristics. The last section presents the conclusions.

\section{Methodology}

We began with a qualitative research approach, followed by a quantitative survey. The qualitative stage included literature review about fruit quality and market tendencies, interviews with fruit and vegetable section managers of three retail distribution chains in Zaragoza, and local market monitoring. The context found in previous studies were much different than from Zaragoza and, therefore, there was a need for more specific information. Thus, focus group with consumers of Zaragoza and interviews were important to complement the problem understanding.

\subsection{Best-Worst Discrete Choice Experiment (BWDCE)}

The quantitative survey included a Best-Worst Discrete Choice Experiment (BWDCE). It was developed by Louviere and Woodworth (Finn \& Louviere, 1992). The method is consistent with Random Utility Theory 
(Luce, 1959) and MNL models (McFadden, 1974). The Marginal approach, which assumes that consumers select first the best and then the worst alternative in each choice set, has been employed in this study.

\subsection{Empirical models and experimental design}

The attributes adopted in the quantitative phase were a result of the previous step. In total, we considered four attributes: (1) fruit origin; (2) type of packing; (3) fruit size; and (4) price. Each attribute had three levels as listed in Table 1.

Table 1. Attributes and levels employed in the experiment.

\begin{tabular}{cccc}
\hline Attribute & Level & Attribute & Level \\
\hline \multirow{3}{*}{ Origin } & From Calanda with PDO & & Smallest \\
& From Calanda without PDO & & Medium \\
& Other places without PDO & Size & Largest \\
\hline \multirow{2}{*}{ Packing } & Active packing & & $1.5 € / \mathrm{kg}$ \\
& No active packing & & $2.5 € / \mathrm{kg}$ \\
& Bulk & Price & $3.5 € / \mathrm{kg}$ \\
\hline
\end{tabular}

${ }^{1}$ Reference levels to estimate effect codes

Price levels were stipulated through market monitoring. In model 2 and 3 (represented by Equation 2 and 3, respectively), price and peach size were considered as quantitative (numeric) variables for estimation purposes and the remaining attributes were considered as categorical (qualitative) variables. Model 1 (Equation 1) was calculated considering fruit size as categorical variable. The qualitative variables were estimated by code effects. Louviere et al. (2000) stated that codes effects are correlated in each attribute but are uncorrelated with the overall mean, unlike dummies. The estimated parameters (beta) should be interpreted as the marginal utility compared to a reference level.

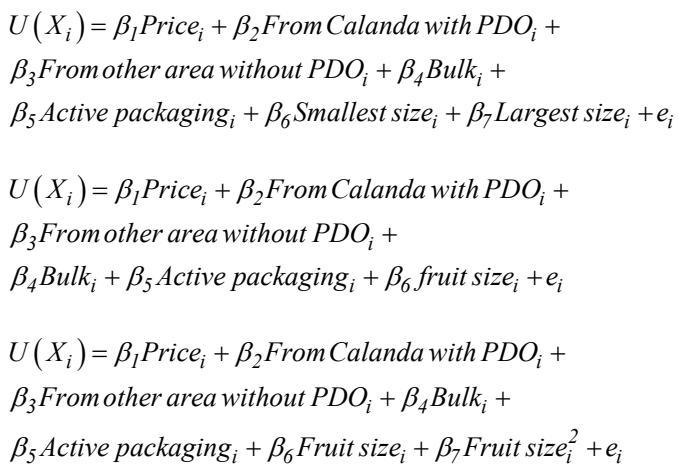

The reference level for the origin is peaches "from Calanda without PDO". The marginal utility between peaches "from Calanda with PDO" and the reference level represents the generic PDO brand value. The marginal utility between reference level and "produced in other places" assesses how much consumers value the production of peaches in the Calanda area, but without the guarantees associated to the PDO brand.

Different peaches sizes were shown to respondents in the interviews. The weight of a smallest peach was about $160 \mathrm{~g}$, a medium size was around $250 \mathrm{~g}$, and the largest one was around $380 \mathrm{~g}$. The first weight corresponds to a peach that would be refused by the PDO norms. The second is the minimum peach size accepted by the PDO norms, and the largest represents a size that almost nobody would be able to eat at once. 
The experiment included two different types of packing, one normal and other active. Respondents were informed that active packing had the same aspect, without implying negative health effects and allowing keeping stocks 12 days more than without active packing.

Preferences are not the same among individuals. Thus, interaction effects were calculated between late season peaches' attributes $\left(\boldsymbol{X}_{\boldsymbol{i}}\right)$ and consumers' socioeconomic characteristics and consumption habits $\left(\boldsymbol{Z}_{\boldsymbol{j}}\right)$

(Equation 4). Consumers' characteristics were coded with dummy variables, taken value 1 when consumer was a woman and zero otherwise; older than 50 years old (zero otherwise); with elementary education, from a family with lower income than 1,500 euros/month; with high loyalty toward PDO Calanda peaches; and consuming them regularly.

$U\left(X_{i}\right)=\sum_{n=l}^{N}\left(\boldsymbol{\beta}_{n} \boldsymbol{X}_{\boldsymbol{i}}\right)+\sum_{m=I}^{M}\left(\boldsymbol{\beta}_{m} \boldsymbol{X}_{i} \boldsymbol{Z}_{j}\right)+e_{i}$

The configuration of the experimental design corresponded to a fractional factorial design. Nine choice sets allowed the estimations of main effects of the attributes' levels of a no label design. In order to obtain unbiased and efficient parameters, attribute levels were combined, following suggestions of Street et al. (2005). Those suggestions allowed generating a balanced and orthogonal design. Its D-efficiency index was checked as suggested by Pihlens et al. (2008) and the design's efficiency was estimated in 100\%. Table 2 provides an example of a choice set.

Table 2. Example of a choice set in the experiment.

\begin{tabular}{lcc}
\hline Least preferable & Situation $\mathbf{4}$ & Most preferable \\
\hline & Alternative A \\
\cline { 2 - 2 } & $2.50 € / \mathrm{kg}$ \\
\cline { 2 - 2 } & From Calanda area with PDO \\
\hline & Bulk \\
\hline & Medium \\
\hline From other area without PDO \\
\hline Normal packing \\
\hline Largest \\
\hline Alternative C \\
\hline From Calanda area without PDO \\
\hline Active packing \\
\hline Smallest \\
\hline
\end{tabular}

\subsection{Data collection and analysis}

The questionnaire was applied to consumers attending two hypermarkets, in the city of Zaragoza (Spain), at the end of October 2008, when the PDO Calanda peaches marketing season was finishing. The reason to undertake the surveys during the marketing season was that consumers should have those products more in mind. Customers were selected randomly. Once data were collected and systematized, estimations were carried out using the biogeme program, version 1.7 (Bierlaire, 2008). 


\section{Results and discussion}

\subsection{Sample profile and late season peach consumption habits}

In total, we collected information from 316 PDO Calanda peach consumers. Sampling errors were estimated for infinite populations, according to guidelines of Trespalacios et al. (2005). Consumers of PDO Calanda peaches were the target population in this study; there was no information about how many consumers of PDO Calanda peaches were in the city of Zaragoza. Thus, we considered the same probability of selecting target and non-target population. Therefore, surveys sampling error estimation is $5.6 \%$.

Consumers' characteristics are shown in Table 3. Proportionally, the sample is overrepresented by consumers who were between 35 and 64 years old. The least represented age class was from 15 to 24 years old. In Spain, per capita consumption of fruit increases with the consumer age (Cerdeño, 2011).

The percentage of women (59.2\%) on the survey was higher than for the overall Aragon population (50.1\%). According to Cerdeño (2006) women are to a great extent responsible for fruits and vegetables purchase in Spain. Madrid (2005) also confirms that women are the ones purchasing food in $66 \%$ of the households.

Surveyed consumers had higher education level, on average, than the average population of Aragon. The percentage of consumers attending college was $31.3 \%$ and elementary school was $27.5 \%$, while in Aragon those percentages were $24.4 \%$ and $34.1 \%$, respectively.

Table 3. Sampled consumers' socioeconomics characteristics.

\begin{tabular}{|c|c|c|c|}
\hline \multirow{2}{*}{ Characteristic } & \multirow{2}{*}{$\begin{array}{l}\text { Sample } \\
\text { Number }\end{array}$} & \multicolumn{2}{|c|}{ Population } \\
\hline & & $\%$ & $\%$ \\
\hline \multicolumn{4}{|l|}{ Consumers'age } \\
\hline From 15 to 24 years & 17 & 5.4 & 11.9 \\
\hline From 25 to 34 years & 62 & 19.6 & 18.4 \\
\hline From 35 to 49 years & 110 & 34.8 & 26.9 \\
\hline From 50 to 64 years & 80 & 25.3 & 20.1 \\
\hline 65 years or over & 47 & 14.9 & 22.7 \\
\hline \multicolumn{4}{|l|}{ Consumers'gender } \\
\hline Female & 187 & 59.2 & 50.1 \\
\hline Male & 129 & 40.8 & 49.9 \\
\hline \multicolumn{4}{|l|}{ Consumers'education } \\
\hline Elementary & 87 & 27.5 & 34.1 \\
\hline High school & 130 & 41.1 & 41.4 \\
\hline College & 99 & 31.3 & 24.4 \\
\hline \multicolumn{4}{|l|}{ Household income } \\
\hline Less than $900 € /$ month & 23 & 7.3 & - \\
\hline From 901 to $1,500 € /$ month & 84 & 26.6 & - \\
\hline From 1,501 to $2,100 € /$ month & 72 & 22.8 & - \\
\hline From 2,101 to $3,000 € /$ month & 81 & 25.6 & - \\
\hline From 3,001 to $4,000 € /$ month & 32 & 10.1 & - \\
\hline More than $4,000 € /$ month & 24 & 7.6 & - \\
\hline Total & 316 & 100.0 & 100.0 \\
\hline
\end{tabular}

People who participated in this study had incomes more centered to around middle levels than households' income in other surveys for the entire Aragon. There was a higher proportion (12.0\%) of low-income level (less than $750 € /$ month) in Aragon than in the survey (7.3\% get less than $900 € /$ month). 
In the survey, consumer stated in $64.9 \%$ of cases that they consumed PDO Calanda peaches more than once a week (Table 4). Smaller percentage of consumers (14.9\%) eats PDO Calanda peaches once each two weeks, $9.8 \%$ once a month and $10.4 \%$ only once during the PDO market season. In this work, those who had consumed PDO Calanda peaches, at least once a week, were considered as regular consumers.

Table 4. PDO Calanda peaches consumption frequency and loyalty degree in the city of Zaragoza.

\begin{tabular}{lcc}
\hline \multicolumn{1}{c}{ Characteristic } & Number & $\%$ \\
\hline More than once a week & PDO Calanda peaches consumption frequency & \\
\hline Once each two weeks & 205 & 64.9 \\
\hline Once a month & 47 & 14.9 \\
\hline Once all season & 31 & 9.8 \\
\hline & 33 & 10.4 \\
\hline High & Loyalty to & PDO Calanda peaches \\
\hline Medium & 213 & 67.4 \\
\hline Low & 31 & 9.8 \\
\hline Total & 72 & 22.8 \\
\hline
\end{tabular}

The survey valued the alternative product to PDO Calanda peach. Consumers were asked which fruit they would buy if PDO Calanda peaches were not available in the market. In total, 17 fruits were mentioned, the main ones were: other peaches ( $23 \%$ of consumers), apples (14\%), oranges $(12 \%)$, bananas $(9 \%)$ and melons (9\%). People who mentioned that they would buy another peach were considered as consumers with the lowest loyalty degree towards PDO Calanda peaches. Those who mentioned that they would buy other kind of stone fruit were considered as consumers with medium loyalty degree. Consumers who would not get another stone fruit were considered as consumers with highest loyalty degree.

Consumers from Zaragoza city were considered loyal to the PDO Calanda brand. Approximately 2/3 of them would buy very distinct fruit if they would not find PDO Calanda peaches in the market, while $22.8 \%$ would buy another peach and $9.8 \%$ would purchase a stone fruit.

\subsection{Main-effects models}

All estimated models in the Table 5 considered that all market had same preferences for late season peaches. As mentioned earlier, peach size was a categorical variable in Model 1 while Models 2 and 3 took into account peach sizes as a numerical variable. The difference between model 2 and 3 is the functional form. Model 2 expresses peach size preferences by a first-degree polynomial whereas Model 3 describes preferences by a second-degree polynomial.

Model 2 results show a positive relationship between peach size and utility. It means that consumers enjoyed large peaches. According to Kays (1998), consumers like large peaches because they have higher relation between flesh (edible) and stone (no edible part), i.e., the preference is based on economics aspects.

Consumers really disliked small peaches. Model 1 shows that consumers had high negative utility $(-0.25)$ when they shifted medium size peaches $(250 \mathrm{~g})$ for the smallest size peaches $(160 \mathrm{~g})$. This negative utility was greater than the positive utility (0.11) of swapping medium size peaches for largest size peaches $(380 \mathrm{~g})$. These results converge to the previous work, such as Bruhn (1995).

California Tree Fruit Agreement (2005) affirm that consumer not only disliked smallest peach sizes, but also the largest peach size was not the most desired size. They found that the most appreciated peach size in USA was between a tennis ball and a baseball. Model 3 results show that in Zaragoza the most desired late season peach size weighs around $254 \mathrm{~g}$ per fruit. This weight corresponds to a $5 \mathrm{~kg}$ box with 20 fruits. 
Table 5. Estimated parameters considering different approaches for peach size.

\begin{tabular}{|c|c|c|c|}
\hline Variable & Model 1 & Model 2 & Model 3 \\
\hline Price & $-0.31 * * *$ & $-0.31 * * *$ & $-0.31 * * *$ \\
\hline From Calanda with PDO & $0.95 * * *$ & $0.94 * * *$ & 0.94 \\
\hline From Calanda without PDO ${ }^{1}$ & -0.08 & -0.08 & $-0.08 * * *$ \\
\hline From other area without PDO & $-0.87 * * *$ & $-0.85 * * *$ & $-0.85 * * *$ \\
\hline Bulk peaches & $-0.03^{\text {ns }}$ & $-0.03^{\mathrm{ns}}$ & $-0.03^{\mathrm{ns}}$ \\
\hline Normal packaging ${ }^{1}$ & 0.18 & 0.18 & 0.18 \\
\hline Active packaging & $-0.15 * * *$ & $-0.15 * * *$ & $-0.15 * * *$ \\
\hline Smallest size & $-0.25 * * *$ & - & - \\
\hline Medium size ${ }^{1}$ & 0.14 & - & - \\
\hline Largest size & $0.11 * * *$ & - & - \\
\hline Peach size $\left(\beta^{*} X\right)$ & - & $0.02^{\mathrm{ns}}$ & $-0,66^{\mathrm{ns}}$ \\
\hline Peach size $\left(\beta * X^{2}\right)$ & - & - & $1,30^{\mathrm{ns}}$ \\
\hline Number of estimated parameters & 7 & 6 & 7 \\
\hline Number of observations & 5,688 & 5,688 & 5,688 \\
\hline Final log-likelihood & $-4,847$ & $-4,914$ & $-4,914$ \\
\hline Adjusted rho-square & $22.3 \%$ & $21.3 \%$ & $21.2 \%$ \\
\hline CAIC & 9,761 & 9,887 & 9,896 \\
\hline
\end{tabular}

The symbol *** represents estimated parameter statistically significant at $1 \%$ and "ns" it is not statistically significant. ${ }^{1}$ The attribute-level of reference.

Traditionally, peaches are sold in boxes (in bulk) at supermarkets' gondola in Spain. However, there is a trend to move toward a wide range of packaging to adapt the product to consumers' needs and tastes. The results show that consumers were indifferent between peaches conditioned in normal packaging and in bulk. Statistically, bulk peaches parameter is not statistically different from zero. This result is the opposite of those found by Campbell et al. (2013) in Canada. They observed that plastic packaging was a viable strategy for increasing peach demand.

Although active packaging has many technical advantages compared to normal packaging, consumers disgusted active packaging. In the models (Table 5), estimated parameters of active packing are negative and statistically different from zero. Probably, there were not enough discussion among consumers about fruit packaging, which made it poorly understood by them. Consumers may also be realizing that the new product could be artificial, which may have negative consequences on health or its taste.

The strongest preferences were observed regarding to production area and PDO brand. Peaches produced in Calanda area without PDO Calanda brand provided higher utility than those produced in other areas without PDO brand. Thus, consumers recognized the existence of the positive link between Calanda production environment and fruit's quality.

Recently, Massaglia et al. (2019) found similar preference in Italy. For Italian consumers, country of origin is the most important attribute on their purchase decision. Local production, which may guarantee the sustainability of local companies, is the fourth most important attribute. The geographical indication and brand are the seventh and tenth most important attributes, respectively. 
Consumers like PDO Calanda Peaches brand. All estimated models show that consumers perceived higher utility with certified peaches by the PDO Calanda Council. The value-added of the PDO Calanda brand occurred for several reasons. The PDO product quality uncertainty was reduced. PDO brand provided more precise indication about the high expected quality of peaches and, consequently, the consumers' ability to match with the observed quality was improved (Menapace et al., 2011).

Tradition was another aspect that explain PDO Calanda brand preference. Previous works suggested that consumers from Zaragoza had clear preference for PDO labels. Espejel et al. (2007a) and Resano et al. (2009) found strong preferences toward PDO Spanish air-cured ham in this place. In this sense, Espejel et al. (2007b) also observed similar preference toward olive oil with PDO "Aceite del Bajo Aragón”.

In summary, Calanda peaches' market strategies may be oriented towards experience attribute-oriented consumers, such as suggested by Zhou et al. (2018), for US consumers. Thus, fruit sweetness and flavor should be improved as much as possible. According to those authors, experience attribute-oriented consumers tend to be less price sensitive.

The price affected peach choice. The estimated value of -0.31 says that consumers perceive a negative utility when peach price increases. This result was expected because, if consumers behave rationally, cateris paribus, they prefer to pay less money for a determined product.

In all models, the number of observations was the same ( 316 consumers * 9 choices set per consumer * 2 choices per choice set $=5,688$ observations). Model 1 explains better the consumers' response variance (Adjusted $\mathrm{R}^{2}=22.3 \%$ ) than model 2 or 3 . Model 1 has the best fit because it has the lowest CAIC.

Although this work presents results in terms of marginal utility, it is important to highlight some previous works. Alfnes \& Rickertsen (2007) and Lusk \& Schroeder (2006) found that hypothetical discrete choice experiment and experimental auction yield same alternatives rank, nevertheless, obtain different WTP values. Normally, auction bids are significantly lower that WTP values estimated through DCE. However, when consumers are more familiar with the product, such as with late season peaches in Zaragoza, the inconsistences between those two methods are smaller (Su et al., 2017; Gracia et al., 2011).

\subsection{Interaction-effect model}

Late season peach market does not have same preference. The heterogeneity of preferences is presented in Table 6. Age influenced the preference for late season peaches. Consumers who were older than 50 years had stronger preference to PDO Calanda Peaches brand. Informally, older consumers said that they had worked in the Calanda area and they maintained relationship with people from this geographical area. Older consumers disliked the largest peach size but had similar disliking for smallest size fruit than younger consumers. Although increasing price for all consumers will decrease utility, older consumers were less sensitive to peach price.

Surprisingly, income did not influence price sensitivity and the attitude toward peach size. In both cases, the interaction between income and peach price or size were not statistically significant. Statistical difference was found between consumer income and preference for production area as well as toward packaging. Low income consumers had less disutility with peaches from other areas and with those sold in bulk.

The preferences of a consumer with elementary education were similar to preferences of those consumers in high school or college. Consumers with elementary education level only disliked more peaches sold in active packaging. Probably, more educated consumers dealt with more innovative environments, and they felt less neophobia against this new presentation. 
Table 6. Interaction effect among late season peaches' characteristics and consumers' characteristics.

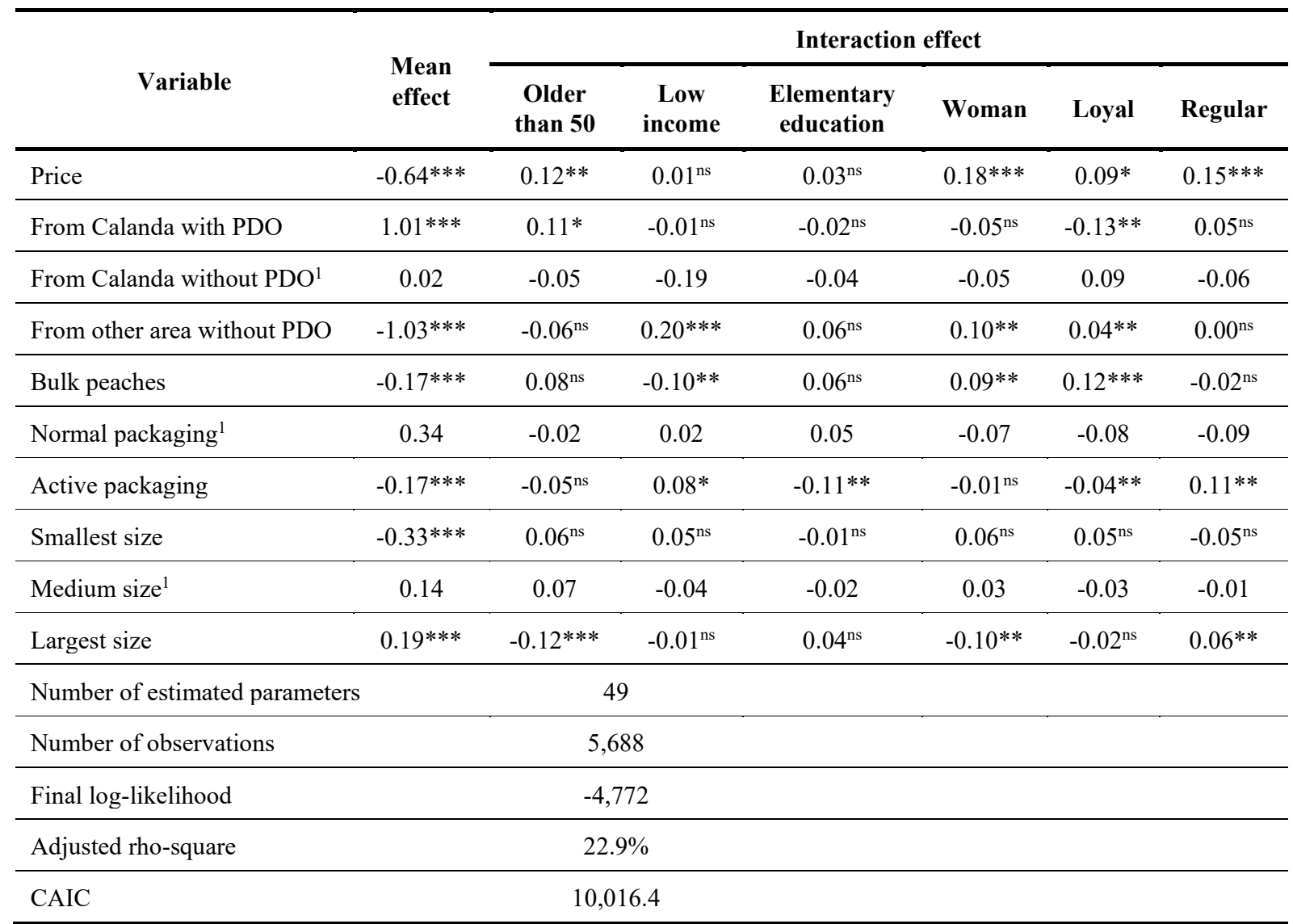

The symbol ***,**, and * represent estimated parameter statistically significant at the $1 \%, 5 \%$ and $10 \%$ levels, respectively, and "ns" it is not statistically significant. ${ }^{1}$ The attribute-level of reference.

Different gender had different preference toward late season peaches. Women had less disutility with prices than men as well as with peaches from other areas coming not from Calanda and with bulk peaches. Women had less utility with the largest peaches than with medium size.

Loyalty degree explains the different preferences concerning price, PDO brand and packaging. Consumers with the higher loyalty degree had smaller disutility with prices. Consumers with highest loyalty degree had stronger preferences for bulk peaches and less preference for PDO Calanda Peaches brand than other kind of consumer. Loyalty degree did not interfere on peach size preference.

Besides having less disutility with price, regular consumers had smaller disutility with active packing. Regarding of different origins, peaches sizes, peaches conditioned in normal packing or in bulk, regular consumers had the same utility than sporadic.

\section{Conclusions}

This study has generated new information of consumers' preferences about peaches consumption in the city of Zaragoza, Spain. This information may guide the private sector in their market strategy in order to obtain higher profits; and the public sector may use the information to develop polices to increase peach consumption.

The reputation of peaches produced in Calanda area has been a consequence of their differentiated quality. The Regulatory Council determines and controls peaches quality, as well as it certificates the product authenticity with their brand. Producing peaches under a PDO brand have been more expensive, but the product may be commercialized with higher prices. 
Consumers differentiate peach quality by origin, and they prefer a product with quality guaranty. Although it was no estimated consumers' willingness to pay for different late season peaches' attributes and there has been no accompanying the certification costs, there were strong indications that PDO Calanda peaches is a good business to accredited growers. Thus, it may contribute to the social and economic development of Calanda area.

Peach size has strong visual attraction and it influenced purchase significantly when different sizes options were offered. Smallest size peaches were the least accepted in the market and, with certain limit, large size was preferred. Not everybody was able to eat one largest size peach $(380 \mathrm{~g})$ at once. On average, the most appreciated peach size was around $254 \mathrm{~g}(5 \mathrm{~kg}$ boxes with 20 fruits), i.e., a medium size fruit.

Packaging has contributed to adapt the product to the modern consumer needs and wishes. Consumers showed a slight preference for normal packing peaches (on average, consumers were statistically indifferent between normal parking and bulk peaches). Considering the objective quality, peaches presented in active packing have higher quality than peaches conditioned in normal packing; however, consumers perceived it as opposite. They valued positively the perishable feature of peaches because they associated it with freshness. In order to contribute to market success of this technological innovation, it is necessary to make efforts to inform consumers that peaches do not lose their freshness and natural properties, because those features are not necessarily related to the eating deadline.

In general, for consumers of Zaragoza, the best late season peach profile was the one in which the fruit was produced in the Calanda area, with the PDO Calanda brand, weighing around $254 \mathrm{~g}$ (5 kg box with 20 fruits), presented in normal packaging or in bulk, and with a price as low as possible.

Preferences heterogeneity was estimated through interaction effects between late season peaches and consumers' characteristics. One model for consumers with different PDO Calanda Peaches consumption frequency (regular and sporadic) had been calculated, other model for loyalty degree (highly loyal or not), and so on for gender, education level (elementary or not), age (younger than 50,50 and older) and household income (less or more than 1,500 €/month). Men and regular consumers preferred larger peaches than women and sporadic consumers. Another finding was that regular consumers as well as those with high loyalty, women and older than 50 years old were less sensitive to price. Thus, the willingness to pay for all attributes levels by these consumers are higher.

It is important to highlight that interviews, which occurred more than 10 years ago, is one of this research limitations. In this period, consumers' preference may have changed, as well as the retail market dynamics. Thus, results should be interpreted with caution.

\section{References}

Aguaviva, D. C. (2015). Mejoras en la producción y comercialización del Melocotón de Calanda: Envasado en bolsas biodegradables y studio de los daños por impacto durante la confección (Trabajo fin de grado). Facultad de Veterinaria, Universidad de Zaragoza, Zaragoza,

Alfnes, F., \& Rickertsen, K. (2007). Extrapolating experimental-auction results using a stated choice survey. European Review of Agriculture Economics, 34(3), 345-363. http://dx.doi.org/10.1093/erae/jbm024

Aragón. Consejo de Agricultura y Alimentación. (2017). Orden DRS/782/2017, de 14 de junho de 2017. Boletin Oficial de Aragón (No. 112, pp. 13973-13989), Zaragoza, Espanha.

Bierlaire, M. (2008). Estimation of discrete choice models with BIOGEME 1.7. Retrieved in 2015, October 15, from biogeme.epfl.ch

Bruhn, C. M. (1995). Consumer and retailer satisfaction with the quality and size of California peaches and nectarines. Journal of Food Quality, 18(3), 241-256. http://dx.doi.org/10.1111/j.1745-4557.1995.tb00378.x

California Tree Fruit Agreement. (2005). Consumer insight: Understanding the California peach, plum \& nectarine consumer. Reedley, California. Retrieved in 2018, September 12, from http://www.sunwestfruit.com/pdf/KeyFindings_Final.pdf

Campbell, B. L., Mhlanga, S., \& Lesschaeve, I. (2013). Consumer preference for peaches attributes: Market segmentation analysis and implications for new marketing strategies. Agricultural and Resource Economics Review, 42(3), 518-541. http://dx.doi.org/10.1017/S1068280500004974 
Cerdeño, V. J. M. (2006). Hábitos de compra y consumo de frutas y hortalizas: Resultados del Observatorio del Consumo y la Distribución Alimentaria. Distribución y Consumo, 88, 5-28.

Cerdeño, V. J. M. (2011). Demanda de frutas y hortalizas en España: Perfiles de consumo conforme a las características de los hogares. Distribución y Consumo, 119, 16-43.

Espejel, J., Fandos, C., \& Flavián, C. (2007a). Spanish air-cured ham with Protected Designation of Origin (PDO): A study of intrinsic and extrinsic attributes influence on consumer satisfaction and loyalty. Journal of International Food \& Agribusiness Marketing, 19(4), 5-30. http://dx.doi.org/10.1300/J047v19n04_02

Espejel, J., Fandos, C., \& Flavián, C. (2007b). La importancia de las denominaciones de origen protegidas como indicadores de calidad para el comportamiento del consumidor: El caso del aceite de oliva del Bajo Aragón. Economía Agraria y Recursos Naturales, 7(14), 3-19. http://dx.doi.org/10.7201/earn.2007.14.01

Finn, A., \& Louviere, J. J. (1992). Determining the appropriate response to evidence of public concern: The case of food safety. Journal of Public Policy \& Marketing, 11(2), 12-25. http://dx.doi.org/10.1177/074391569201100202

Gracia, A., Loureiro, M. L., \& Nayga Junior, R. M. (2011). Are valuations from nonhypothetical choice experiments different from those of experimental auctions? American Journal of Agricultural Economics, 93(5), 1358-1373. http://dx.doi.org/10.1093/ajae/aar054

Iglesias, I. (2017). L'innovation variétale Pêche/Abricot en Espagne. Retrieved in 2018, September 10, from http://www.cothn.pt/publicfiles/zhinwzdy7uxc3ogiree6opgwcqodotapitmepimm.pdf

Kays, S. J. (1998). Preharvest factors affecting appearance. Postharvest Biology and Technology, 15(3), 233-247. http://dx.doi.org/10.1016/S0925-5214(98)00088-X

Louviere, J. J., Hensher, D. A., \& Swait, J. (2000). Stated choice methods: Analysis and application. Cambridge: Cambridge University Press. http://dx.doi.org/10.1017/CBO9780511753831.

Luce, R. D. (1959). Individual choice behaviour. New York: Wiley.

Lusk, J. L., \& Schroeder, T. C. (2006). Auction bids and shopping choices. Advances in Economic Analysis \& Policy, 6(1), 1-37. http://dx.doi.org/10.2202/1538-0637.1539

Madrid. Cámara Oficial de Comercio, Industria y Servicios de Madrid. (2005). La compra de alimentos en los hogares madrileños: Cambios en la última década: Encuestas de consumo en la Comunidad de Madrid. Retrieved in 2010, July 10, from http://www.camaramadrid.es/asp/pub/docs/la_compra_de_alimentos_en_los_hogares_madrilenos_cambios_en_la_ultima_deca da.pdf

Massaglia, S., Borra, D., Peano, C., Sottile, F., \& Merlino, V. M. (2019). Consumer preference heterogeneity evaluation in fruit and vegetable purchasing decision using the best-worst approach. Foods, 8(266), 266. http://dx.doi.org/10.3390/foods8070266

McFadden, D. (1974). Conditional logit analysis of quantitative choice behaviour. In P. Zarembka (Ed.), Econometrics (pp. 105142). New York: Academic Press.

Menapace, L., Colson, G. J., Grebitus, C., \& Facendola, M. (2011). Consumer's preferences for geographical origin labels: Evidence from the Canadian olive oil market. European Review of Agriculture Economics, 38(2), 193-212. http://dx.doi.org/10.1093/erae/jbq051

Pihlens, D. A., Street, D. J., \& Burges, L. (2008, July). Designing generic discrete choice experiments. In I Workshop on Valuation Methods in Agro-Food and Environmental Economics: State-of-the Art Future Challenges in Stated Choice Experiments. Casteldefels, Barcelona: Fundación Creda.

Resano, H., Sanjuán, A. I., \& Albisu, L. M. (2009, September). Evidence on the value of EU quality certification schemes: The case of dry-cured ham in Spain. In Abstracts of the 113th EAAE Seminar: A Resilient European Food Industry and Food Chain in a Challenging World. Chania, Crete: European Association of AE. CD-ROM.

Street, D. J., Burgess, L., \& Louviere, J. J. (2005). Quick and easy choice sets: Constructing optimal and nearly optimal stated choice experiments. International Journal of Research in Marketing, 22(4), 459-470. http://dx.doi.org/10.1016/j.jiresmar.2005.09.003

Su, L., Adam, B. D., Lusk, J. L., \& Arthur, F. (2017). Anchoring, information, and fragility of choice experiments: An application to consumer willingness to pay for rice with improved storage management. Journal of Agricultural and Resource Economics, 42(2), 255-274

Trespalacios, J. A., Vázquez, R., \& Bello, L. (2005). Investigación de mercados. Madrid: Ed. Thomson.

Voicu, M. C. (2013). Characteristics of the consumer preferences research process. Global Economic Observer, 1(1), $126-134$.

Zhou, R., Yue, C., Zhao, S., Gallardo, R. K., Mccracken, V., Luby, J. J., \& McFerson, J. R. (2018). Using market segmentation analysis to identify consumer preferences for fresh peach attributes. HortScience, 53(11), 1664-1668. http://dx.doi.org/10.21273/HORTSCI13182-18

Funding: Support by INIA project, financed with FEDER founds $x$ PET 2007-09_C5. 